\title{
The reaction of American Luxury tourists visiting Rwanda during 2018-2019 Ebola outbreaks
}

\author{
James Ngamije \\ Department of Community Development, University of Tourism Technology and Business Studies, Rwanda, \\ Research director Rwanda Youth Impact, Rwanda Green Crescent. \\ ngamije2009@gmail.com
}

Received: 19/11/2020 Revised: 5/12/2020 Accepted: 14/12/2020 DOI: https://doi.org/10.31559/IJHTS2020.1.2.7

\begin{abstract}
:
Several cases of Ebola virus diseases (EVD), have been discovered in Africa. The 2018-2019 outbreak of the Ebola virus disease (EVD) in North Kivu and Ituri provinces has been declared International public health emergency. Rwanda as a neighboring country was on high alert, with the possibility of the disease crossing its borders. As a result, some countries, issued travel alerts to their citizens to avoid travel to Congo or nearby countries to include Rwanda. This study investigates the impact of Ebola outbreak on American Luxury tourists in Rwanda, evaluating its findings in light of the 2018-2019 outbreak of Ebola virus disease (EVD) in Democratic Republic of Congo. It concludes that this EVD did not discourage this target group of tourists from undertaking their planned itineraries in Rwanda.
\end{abstract}

Keywords: Ebola virus disease; Tourism; American Luxury tourists; Rwanda.

\section{Introduction}

The increasing emphasis on tourism as an engine of Africa' economic growth is due to not only its climate but also gifted with fascinating attractions, which makes this country attractive to tourists. For example, global tourism arrivals in 2019 increased to 1,5 billion, a 4\% increase of a previous year and representing the tenth year of consecutive growth (UNWTO, 2020). Luxury tourism market is seen as a possible strategy of growth for developing countries and an agent of development because of its potential to contribute to the economy growth of tourism destinations by increasing socio-economic on the livelihoods of poor in rural areas (Mwai, 2019), employment opportunity, developing infrastructure, and attracting foreign exchange earnings. However, one cannot ignore the necessity of development and innovation in the agricultural sector. However, no one should ignore the costs, risks and impacts of social and environmental impacts on both tourist and community living in tourism destination.in addition to safety concern, two Ebola virus disease (EVD) outbreaks in Africa raised a concern to the tourism industry.

The 2018-2019 outbreak of the Ebola virus disease (EVD) in North Kivu and Ituri has been declared International public health emergency (WHO,2019). In 2019, Rwanda was on high alert as the Ebola case was confirmed in Goma, with the possibility of the disease crossing its borders. As a result, some countries advised their citizens to avoid travel to infected areas. According to Ries (2019), the Centers for Disease Control and Prevention (CDC) issued a level two travel warning to their citizens to avoid essential travel to the affected areas or nearby countries to include Rwanda or take special safety measures.

\section{Description of terms}

The name of Ebola virus disease (EVD) came from Ebola River in DRC and is a member of Filoridae family. Currently, there are five types of Ebola identified: Zaire (actual DRC), Sudan, Bundibugyo, Ta"1 Forest and Reston. Zaire, Sudan and Bundibugyo make fatal illness in human beings with case fatality rates ranging from $25 \%$ to $90 \%$ (Kraemer et al, 2020) EVD has significant epidemic potential and affect tourism sector, as shown by the 20132016 West African outbreak (Alive2green,2015). The Ebola outbreak in West Africa was unique, being larger than all previous outbreaks combined since first Ebola outbreak in 1976, with the total of 28646 reported cases and 11 
323 death cases (Coltart et al., 2017). The current 2018-2019 outbreak of the Ebola virus disease (EVD) in North Kivu and Ituri also known 11th Ebola outbreak was also the largest outbreak that has occurred in DRC since the first Ebola outbreak in 1976, and is the second largest of all Ebola outbreaks after the 2014-2015 West Africa outbreak with 3262 cases and 2232 deaths (Shears and Garaven, 2020).

\section{Action and reaction of tourists}

Based on past experience, tourism and hospitality related stakeholders needed to be better prepared, in terms of emergency preparedness and working with government to deal recent 2018-2018 Ebola outbreaks. EVD has significant epidemic potential and affect tourism sector, as shown by the 2013-2016 West African outbreak (Alive2green,2015). In the past the Ebola virus outbreak of 2014-2015 in countries such as Guinea, Liberia and Sierra Leone, research showed that Ebola scared off many tourists and have affected tourism in African countries. For example, In Africa $50 \%$ of tour operators reported that they experienced cancellations due to fears of the virus. Despite the large distance involved South African tourism also experienced declines in tourism business due to the same problem. In October 2014, the Hotels Association of Tanzania reported a 30\% to $40 \%$ declined in tourism business compared to 2013(Alive2green,2015).

On 14th July 2019 the first case of Ebola was reported in Goma Town very close to Rubavu district in Rwanda with the small boarder and large boarder. Learning from Learning for 2013-2014 Ebola outbreaks, World Health Organization requested Rwanda not to close borders to avoid illegal entries but to coordinate crisis management and implement communication plans in country. WHO Director-General Tedros Adhanom Ghebreyesus praised the actions taken by Rwanda and confirmed that there have been no cases of Ebola reported in Rwanda, despite high levels of traffic and movement between Goma and Rubavu at least more than 55,000 people per day(WHO,2019). In response to this crisis, Rwanda trained health workers in early detection and response, educating communities including tourism stakeholders about Ebola, screening for Ebola symptoms at points of Entry and vaccinated health workers (WHO,2019) and community living at the border with DRC.

\section{The image of Rwanda and luxury tourists}

Rwanda as one of East African countries is a land of thousand hills often known as Switzerland of Africa bordered by Uganda in the North and North-East, Burundi in the South and Democratic Republic of Congo, and Tanzania in North East. Rwanda is beautiful and gifted with fascinating attractions, which makes this country attractive to tourists. Due to its size with only 26,338 square kilometers, good infrastructure and safe for both community and visitors enables tourists to visit most of the attractions in few days as many tourism attractions are close to each other. Despite 1994 genocide against Tutsi, Rwanda is now ranked as a new luxury travel destination in Africa.

The optimism for achieving the set target despite the economic and political headwinds in its attraction to luxury tourists is fuelled by the good governance of HE Paul Kagame supported by government bodies who invested in the domain of logistics, infrastructure, connectivity and the knowledge economy (LICK). In less than decade, large numbers of projects and luxury hotel development opportunities have been shown in Rwanda. Most notable are the opening of excellent lodges (e.g Bisate Lodge in Volcanoes national park), hotels (e.g Radison Blu within Kigali Convention Center, Marriot hotel, Cerena Hotel) and camps (Magashi tented camp on shores of lake Rwanyakanzigain Nyungwe national park). Further projects contributing to luxury tourism destination include Rwanda air with direct flights to Africa, America and European countries, center of MICE(ranked as the leading destination for meetings, incentives, conference and events attracting the highest number of conference travellers from all part of the worlds), and virunga volcanoes. The expensive gorilla tour packages, in addition to luxury lodge, hotels and camps all over the country make researchers continue to question Rwanda' luxury image, possibly reason for making this country ranked among top ten American luxury tourists (Bizimungu, 2019; West,2019). However, due to Ebola 2013-2014 CDC issued travel notice during the 2018-2019 outbreaks of the Ebola virus disease (EVD) in DRC and nearby countries (Ries,2019); Rwanda tourism market of luxury tourists should have been negatively affected. This study seeks to identify the Impact of the 2018-2019 outbreak in (DRC) on American Luxury tourists to Rwanda.

This study focuses on the following hypotheses:

\section{Hypothesis 1:}

Ebola outbreak of 2018-2019 in DRC did not affect luxury tourism market in Rwanda, especially American luxury tourists, since the country is very safe, and well organized to effectively control the infection to enter the country.

Hypothesis 2:

American Luxury tourists continued to visit Rwanda because of tourism strategy to target this market 


\section{Methodology}

This study relies on luxury tourism statistics published on various websites. Data are studied to measure the difference in tourism patterns, including those of the American luxury tourism, in three years: 2017, 2018, and 2019. These years were specifically chosen, since 2018-2019 Ebola outbreaks were reported in the second of them. If this disease affected travel trends in Rwanda among American Luxury Tourists, noticeable changes would have occurred in the numbers of tourists visiting volcanoes park hosting gorillas in that period.

\section{Research model}

Research model used in this study is deductive method. Deduction entails moving from the general to the particular, as it start from an existing theory (EVD have negative impact on tourism), formulate hypothesis (see hypothesis formulated), collect data to test the hypothesis, and analyse the results to found out if the data reject or support the hypothesis (Locke, 2007). A deductive method is used to analyse the data on American luxury tourists in Rwanda taken from the websites; the data are compared to determine which are most accurate. In addition, a literature review has also been conducted in order to have comprehension into the theories, methods, and deductions of other scholars.

\section{Findings}

Rwanda received was warned about the 2018-2019 Ebola outbreaks in Democratic republic of Congo, particularly in North Kivu and Ituri. Despite warnings related to travel in DRC and nearby countries, Rwanda accommodated 1.711 million visitors. International tourists increased by $8 \%$ compared to 2017 . Revenue from Gorilla trekking permits in Volcanoes National Park performed attracting luxury tourists excel during 2018-2019 EBV, recording 25 per cent growth from 2017 to $\$ 19.2 \mathrm{M}$. In all, 1.711 million tourists were on the move in Rwanda, of which from sale of 15,132 gorilla permits during the year. In addition, revenue from Gorilla trekking permits in Volcanoes National Park grew by 25 per cent in 2018 to $\$ 19.2 \mathrm{M}$ from 2017. Despite the flow in prices, luxury tourists from the United States grew 114\%, along with those from China, Australia and Nigeria constituted the highest number of visitors that reportedly grew eight per cent to 1.7 million last year from 1.3 million in 2017. Report on American luxury tourists during 2018-2019 EVD showed that Rwanda was among the top 10 countries that have experienced significant increases by percentage in year-over-year bookings among American travellers at 114 per cent.

In 2019, however, the number of visitors reduced with over 1.6 million visitors may be due to Ebola fears particularly in July with the first case reported in Goma. However, in that year, Rwanda had over 17,249 visited mountain gorillas in volcanoes National park. In the same year, the increase on the park permits sold at 25 percent growth rate, giving the nation USD 28.9 million, compared to 2018.

Table (1): Volcanoe's number of gorilla permit's and revenue since 2017

Table (1): Volcanoe's number of gorilla permit's and revenue since 2017
\begin{tabular}{|l|l|l|l|l|}
\hline Year & Visitors(million) & Gorilla permits & Revenue (USD) & Percentage \\
\hline 2017 & 1.7 & 10,240 & $15.7 \mathrm{M}$ & $14.1 \%$ \\
\hline 2018 & 1.711 & 15,132 & $19.2 \mathrm{M}$ & $25 \%$ \\
\hline 2019 & 1.6 mill & 17,249 & $28.9 \mathrm{M}$ & $25 \%$ \\
\hline & & & & \\
\hline
\end{tabular}

Source: Rwanda Development Board (RDB)

\section{Analysis}

In comparing all visitors coming in Rwanda and luxury tourists during 2018-2019, several common trends can be identified. Although Rwanda attracts luxury tourists all over the world, most of the luxury tourists that came to Rwanda during 2018-2019 EVD are from America. The number of tourists increased in 2018 but reduced in 2019. However, number of luxury tourists visiting Gorillas increased in 2019 and Gorilla national parks revenue from Gorilla trekking permits grew by 25 per cent in two years 2018 and 2019. Our data analysis suggests that the number of luxury tourists varied little in 2018 and increase in 2019 the year of the Ebola case reported in Goma, a city closed to Rwanda with high traffic per day. Remarkably, there was no decline in the number of luxury tourists arriving in Rwanda. There are several possible explanations for this resilience of luxury tourists in Rwanda during 2018-2019 EVD: (i) Luxury tourists like other usual tourists, ignored warnings against travel to DRC and nearby countries such as Rwanda. The report from WHO with regards to Rwanda preparedness and control of Ebola let them believe that this disease did not cross the border. (ii) the health sector's response to this international emergency may also have convinced tourists to modulate the threat. (iii) The fact that the health experts revealed that Ebola is extremely rare in travelers and not an easy virus to get as it does not get transmitted through the air like the influenza virus does may also have indicated that they are safe from being 
infected(West,2019). (iv) most Luxury tourists in Rwanda are from America with families and relatives who may be regular luxury tourists, which might explain their motivation to visit despite level two travel notice issued by CDC, since they are aware that risk areas are far from Rwanda with potential to stop Ebola coming in Rwanda.

\section{Data limitations and assumptions}

This study was limited by the lack of published data detailing the number of luxury tourists visiting Rwanda. For example, although there were data detailing the increasing number of American luxury visitors, the origins of other tourist visitors is unknown. Hypothesis 1 , therefore, is proven, since there seems to have been little fear among international tourists particularly American luxury tourists to visit Rwanda even in the height of Ebola outbreak in DRC in 2018.

\section{Conclusion}

Tourism is a very sensitive industry. Negative publicity surrounding a tourist destination often results in cancellation of travel due to fear. Indeed, often even a slight risk, especially in regard to human safety (disease such as malaria, road accidents, terrorism, etc.), is enough to spur a drastic change of fortune for tourist destinations (West,2019). It therefore seems extraordinary that the numbers of American luxury tourists, who visited Rwanda in 2018 and 2019, during Ebola outbreak in DRC fears, were not drastically affected. It appears that most of these tourists were convinced that Ebola is extremely rare in travelers and not easy virus to get while traveling to nearby countries such as Rwanda.

\section{Conflict of Interest:}

The authors declares that there is no conflict of interest

\section{References:}

[1] Alive2green. Com. (2015). Available from: on http://alive2green.com/ebolas-impact-tourismafrica [Accessed on 2020 February 11]

[2] Bizimungu, J. (2019). "Revenue from Gorilla tourism grows by 25\%". Newtimes [Online] August 21 (2019) https://www.newtimes.co.rw/news/revenue-gorilla-tourism-grows-25

[3] Coltart CEM, Lindsey B, Ghinai I, Johnson AM \& Heymann DL. (2017). "The Ebola outbreak, 2013-2016: old lessons for new epidemics". Phil. Trans. R. Soc. B 372 : 20160297. http://dx.doi.org/10.1098/rstb.2016.0297

[4] Kraemer, M.U.G., Pigott, D.M., Hill, S.C. et al. (2020). "Dynamics of conflict during the Ebola outbreak in the Democratic Republic of the Congo 2018-2019”, BMC Med. 18113 (2020), https://doi.org/10.1186/s12916-020-01574-1

[5] Mwai,C. (2019). "Luxury US tourists to Rwanda grow by 114\%, travel agencies say". Newtimes, [Online] August 19, 2019 https://www.newtimes.co.rw/business/luxury-us-tourists-rwanda-grow-114-travel-agencies-say

[6] Ries J. (2019). "What travelers should know about the Ebola Outbreak: The CDC has issued a warning for people traveling to the Democratic Republic of Congo". Health News [Online]July24, 2019 https://www.healthline.com/health-news/here-arethe-travel-bans-for-the-ebola-outbreak

[7] Shears P. \& Garavan, C. (2020). "The 2018/19 Ebola epidemic the Democratic Republic of the Congo (DRC): epidemiology, outbreak control, and conflict", Infection Prevention in Practice. 2(1), https://doi.org/10.1016/j.infpip.2020.100038

[8] UNWTO (2020), "International tourism growth continues to outplace the global economy", available at: https://unwto.org/international-tourism-growth-continues-to-outpace-the-economy. [cited 2020 December 2]

[9] West, B. (2019). Why the latest ebola outbreak shouldn't stop you visiting East Africa. Independent [Online] July 18,2019 https://www.independent.co.uk/travel/africa/ebola-outbreak-tourism-east-africa-danger-who-health-travela9010486.html[cited 2020 November 18]

[10] World Health Organization (WHO). (2019). Ebola outbreak in the Democratic Republic of the Congo declared a Public Health Emergency of International Concern. Available from: https://www.who.int/news-room/detail/17- 07-2019-ebolaoutbreak-in-the-democratic-republic-of-the-congo-declared-apublic-health-emergency-of-international-concern. $\quad$ [cited $\quad 2020$ November 11].

[11] World Health Organization (WHO). (2019). WHO applauds Rwanda's Ebola preparedness efforts? 2019. Available from: https://www.who.int/news/item/24-07-2019-who-applauds-rwanda-s-ebola-preparedness-efforts [Accessed 2019 November 11] 